\title{
Description of a new species of Potamonautes MacLeay, I 838, from the iSimangaliso Wetland Park, South Africa
}

\author{
Nasreen Peer', Renzo Perissinotto', Gavin Gouws², Nelson A.F. Miranda' \\ I DST/NRF Research Chair in Shallow Water Ecosystems, Nelson Mandela Metropolitan University, PO Box \\ 77000, Port Elizabeth 6031, South Africa 2 South African Institute for Aquatic Biodiversity (SAIAB), Private \\ Bag 1015, Grahamstown, 6140, South Africa
}

Corresponding author: Nasreen Peer (peer.nasreen@gmail.com)

Academic editor: S. De Grave | Received 5 March 2015 | Accepted 27 April 2015 | Published 11 May 2015

http://zoobank.org/305BDD0E-C8EA-4D4B-A280-4AF2CD7348F5

Citation: Peer N, Perissinotto R, Gouws G, Miranda NAF (2015) Description of a new species of Potamonautes MacLeay, 1838, from the iSimangaliso Wetland Park, South Africa. ZooKeys 503: 23-43. doi: 10.3897/zookeys.503.9532

\begin{abstract}
A new species of freshwater crab, Potamonautes isimangaliso sp. n., is described from the western shores of False Bay, Hluhluwe, within the iSimangaliso Wetland Park, South Africa. While bearing a superficial resemblance to $P$. lividus, the new species has been found to be genetically distinct, diverging from the former by $7.4-7.8 \%$ in mtDNA. Potamonautes isimangaliso most closely resembles $P$. lividus, but is distinguished by a unique suite of carapace characters, colouration, and size. The new species also lives in close association with oxygen-poor, fresh ephemeral pans, while the habitat of P. lividus is well above the surface water line of the closest water body. An updated identification key for the Potamonautes species of South Africa is provided.
\end{abstract}

\section{Keywords}

Brachyura, freshwater, Potamonautes, taxonomy, ephemeral pans, sand forest, iSimangaliso Wetland Park

Copyright Nasreen Peer et al. This is an open access article distributed under the terms of the Creative Commons Attribution License (CC BY 4.0), which permits unrestricted use, distribution, and reproduction in any medium, provided the original author and source are credited. 


\section{Introduction}

Freshwater crabs play a key role in ecosystems by serving as an important food source for larger taxa, and recycling nutrients through detritivorous feeding habits (Cumberlidge 2009). They link terrestrial and aquatic habitats by moving between the two systems, and are considered bioindicator species of environmental change in some habitats (Schuwerack et al. 2001). Potamonautes is the only genus of primary freshwater crab (Yeo et al. 2014) in South Africa, with 16 described species occurring in the country, two having been described in recent years (Daniels and Bayliss 2012; Phiri and Daniels 2014).

The iSimangaliso Wetland Park forms the southernmost region of the Maputaland centre of endemism and constitutes the focus of biodiversity conservation in the region (Smith et al. 2008). Recent ecological and biodiversity surveys of Lake St Lucia have been conducted in an attempt to update local taxonomic records, identify undescribed species, highlight the change in diversity over time, and provide illustrated and annotated checklists to use as identification tools (Nel et al. 2012; Peer et al. 2014; Perissinotto et al. 2014). Surveys have revealed the existence of an undescribed species of Potamonautes along the western shores of False Bay (Fig. 1) that most closely resembles P. lividus Gouws, Stewart \& Reavell, 2001 in morphological appearance, exhibiting a rounded vaulted carapace and the potential ability to spend a large amount of time out of water. However, genetic analysis showing a 7.4-7.8\% difference across the combined $16 \mathrm{~S} \mathrm{rDNA}$ and COI gene fragments in comparison to P. lividus (G. Gouws unpubl.) and morphological analysis (present study) indicate that the two species are indeed distinct.

In this paper we describe Potamonautes isimangaliso sp. $\mathrm{n}$. from the sand forests of the iSimangaliso Wetland Park. NP and GG wrote the taxonomic part of this study, including the description of the new species, while the contribution of the other authors dealt with natural history and ecological observations.

\section{Materials and methods}

\section{Collection of crabs}

Crabs were collected from four localities (Fig. 1) using a sweep net in pans or by active hand capture. The unidentified species was found in 2012-2013 during routine surveys in the area as part of an ongoing project on the biodiversity of Lake St Lucia, supported by the iSimangaliso Park Authority and the provincial conservation authority, Ezemvelo KZN Wildlife, and subsequently during a dedicated survey undertaken in February 2015. Specimens were preserved in 10\% formalin or $70 \%$ ethanol, once photographs were taken using a Canon Powershot G12. 


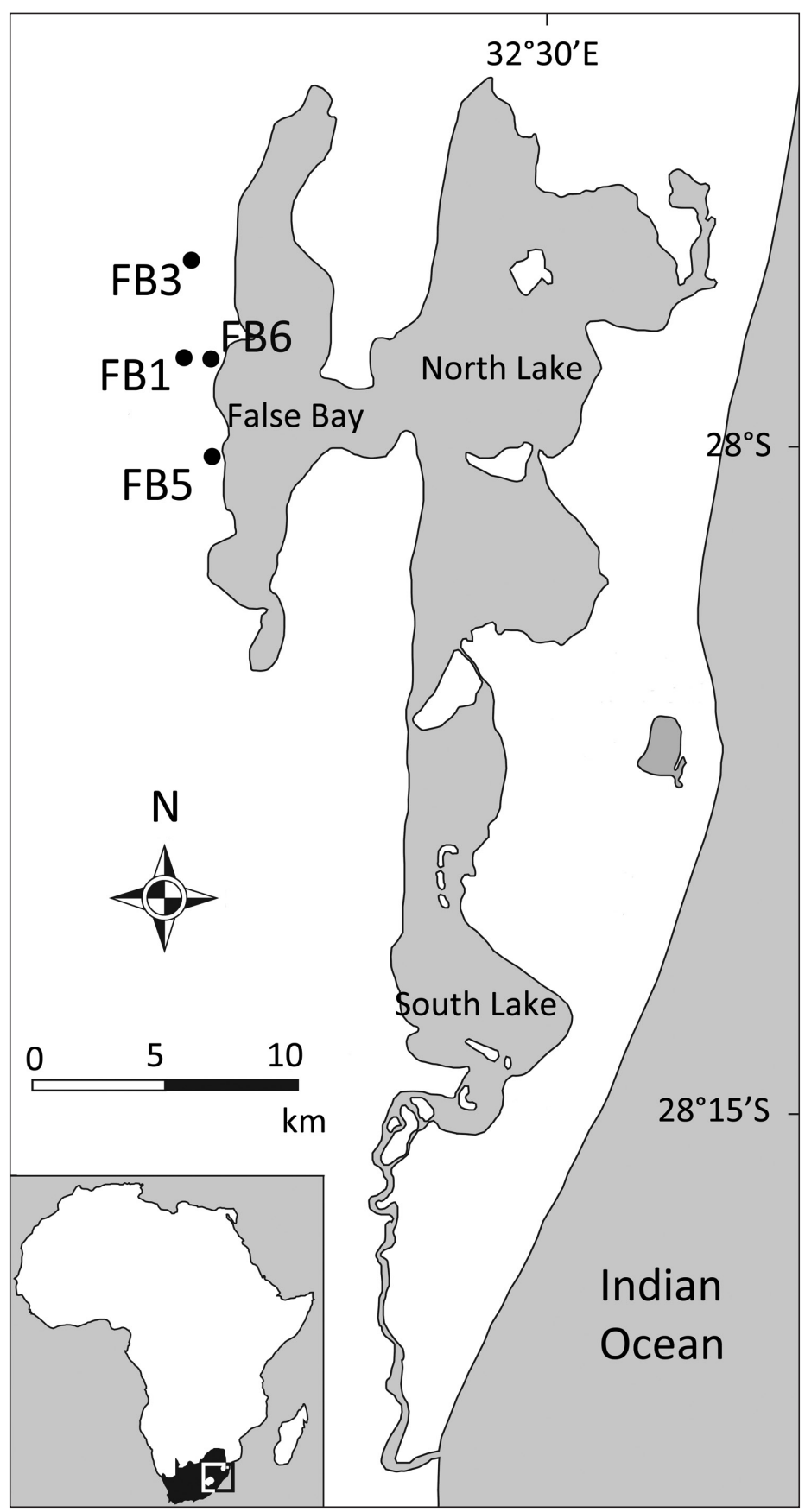

Figure I. Map of Lake St Lucia on the east coast of South Africa. Collection localities, indicated by black dots and labelled with codes, are all restricted to the western shore of False Bay, within the False Bay Park. FB1 = Main Road Pan; FB3 = Mpophomeni Pan; FB5 = Dukandlovu Pan; FB6 = Sandy Point Pan. 


\section{Morphological and morphometric analyses}

In the laboratory, a pair of Vernier callipers was used to measure morphological variables. A Nikon SMZ25 microscope fitted with a Nikon Digital Sight DS-Fi2 camera was used for macro-examination and to take photos of gonopods and mouthparts.

Abbreviations for depositories and provinces:

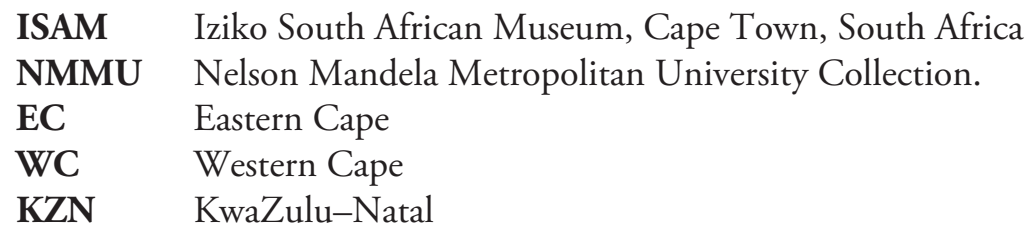

Abbreviations for all morphological and morphometric characters (Gouws et al. 2001)

$\begin{array}{ll}\text { CL } & \text { Carapace length } \\ \text { CWW } & \text { Carapace widest width } \\ \text { CWP } & \text { Carapace posterior width } \\ \text { PFCD } & \text { Distance between postfrontal crest and anterior margin } \\ \text { ED } & \text { Distance between orbits } \\ \text { CWA } & \text { Distance between exorbital teeth } \\ \text { CH } & \text { Carapace height } \\ \text { AW6 } & \text { Width of sixth abdominal segment } \\ \text { MCPL } & \text { Major cheliped propodus length } \\ \text { MCPH } & \text { Major cheliped propodus height } \\ \text { P2ML } & \text { Pereopod 2, merus length } \\ \text { P2MH } & \text { Pereopod 2, merus height } \\ \text { s2/s3 } & \text { First sternal groove (suture between the second and third sulci) } \\ \text { s3/s4 } & \text { Second sternal groove (suture between the third and fourth sulci) } \\ \text { CRDL } & \text { Right cheliped, dactyl length } \\ \text { CLDL } & \text { Left cheliped, dactyl length } \\ \text { CRPL } & \text { Right cheliped, propodus length } \\ \text { CLPL } & \text { Left cheliped, propodus length } \\ \text { CRPW } & \text { Right cheliped, propodus width } \\ \text { CLPW } & \text { Left cheliped, propodus width } \\ \text { ML } & \text { Merus length } \\ \text { MW } & \text { Merus width }\end{array}$

For the morphometric analyses, eight variables (CL, PFCD, CWP, ED, $\mathrm{CH}$, AW6, CRPL and CRPW) were log transformed and used to run a stepwise discriminant function analysis in STATISTICA v 12.5 (Statsoft 2004). Data for Potamonautes lividus were obtained from G. Gouws and represent the specimens used for the de- 
scription of P. lividus (Gouws et al. 2001). Classification functions were calculated and individuals were then reassigned to groups based on a priori probabilities. Canonical scores were plotted for both species on a frequency histogram to support distinction between the two forms. Lastly, a linear regression analysis was used to examine variation for specific variables.

\section{Genetic analysis}

DNA was extracted from each specimen and amplification of the mitochondrial cytochrome c oxidase subunit I (COI) and 16S ribosomal DNA genes were carried out following protocols outlined by G. Gouws (unpubl.). Amplifications were confirmed by electrophoresis in $1 \%$ agarose gels with an ethidium bromide stain. The product was then viewed on an ultraviolet transilluminator. Sequences were generated from a representative of the new species, using approaches described elsewhere (Daniels et al. 2002; Phiri and Daniels 2014; G. Gouws (unpubl.)).

\section{Results}

\section{Morphometric analysis}

The new species (Potamonautes isimangaliso sp. n.) was distinguished from P. lividus by its larger size, flatter carapace and more rounded posterior. The carapace variables $\mathrm{CL}, \mathrm{CH}$ and CWP contributed the most to distinguishing between the two forms in the discriminant analysis. Fig. 2 highlights the morphometric distinction between the two species.

The classification function was calculated for both species as follows:

$\mathrm{Y}(P$. isimangaliso $)=926.798(\log C \mathrm{~L})-602.076(\mathrm{Log} C H)-7.966(\log C W \mathrm{P})-178.319$

and

$\mathrm{Y}($ P. lividus $)=1428.33(\log C \mathrm{~L})-743.234(\log C H)-321.805(\log C W P)-296.179$

Individuals were reassigned to groups based on a priori probabilities using these classification functions. $100 \%$ of both forms were correctly classified with no individuals being reassigned. Three variables (CWP, PFCD and $\mathrm{CH}$ ) were regressed over CL and a significant difference was seen between the two species as follows: CWP/CL $-S S$ $=0.1, \mathrm{df}=2, \mathrm{~F}=2.29, \mathrm{p}<0.001 ; \mathrm{PFCD} / \mathrm{CL}-\mathrm{SS}=0.1, \mathrm{df}=2, \mathrm{~F}=2.29, \mathrm{p}<0.001$; $\mathrm{CH} / \mathrm{CL}-\mathrm{SS}=0.1, \mathrm{df}=2, \mathrm{~F}=5.99, \mathrm{p}<0.001($ Fig. 3a, b, c) 


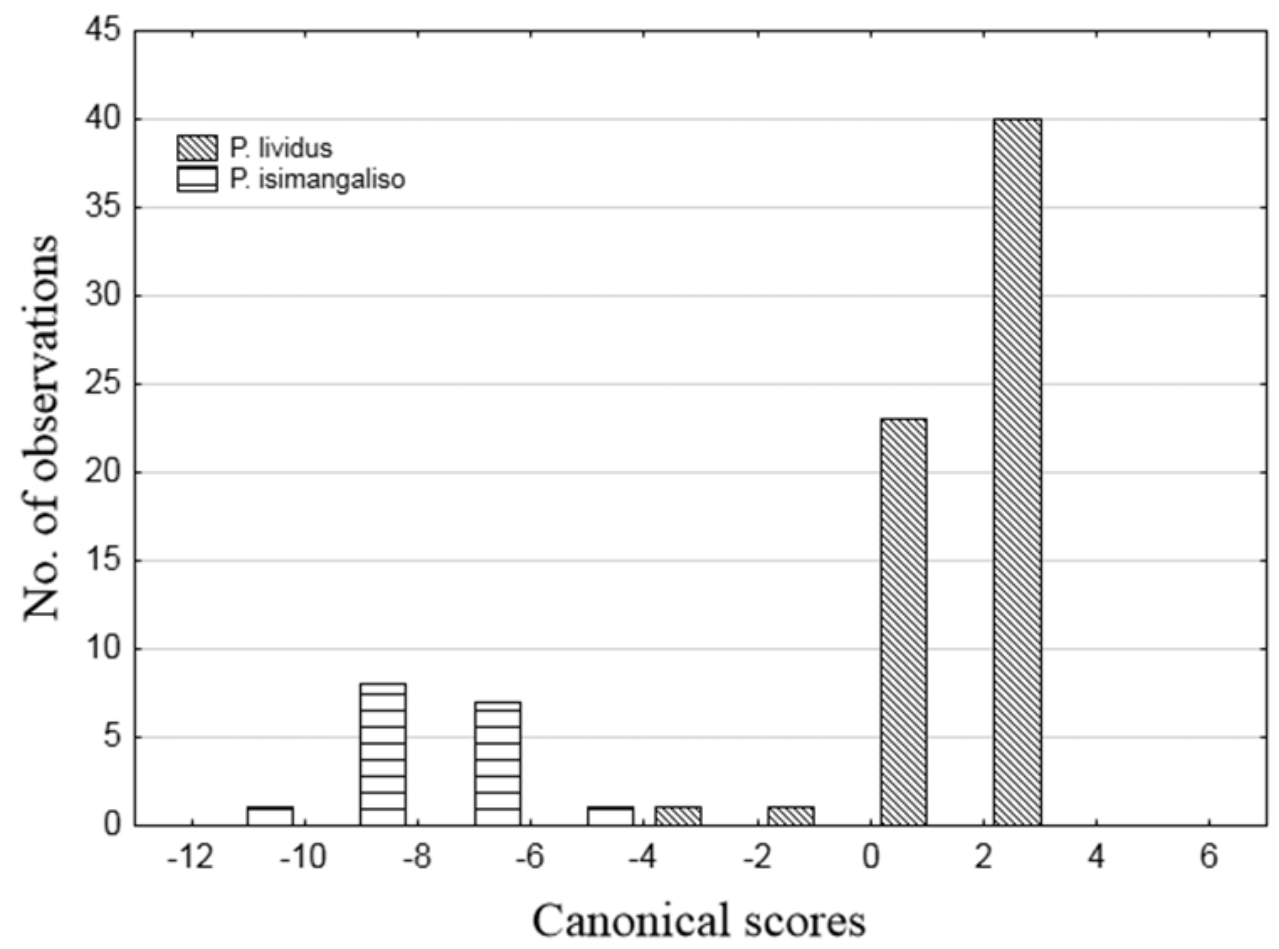

Figure 2. Histogram of canonical scores for $P$. isimangaliso and $P$. lividus calculated from a discriminant function analysis.

\section{Taxonomic description}

\section{Potamonautes isimangaliso Peer \& Gouws, sp. n.} http://zoobank.org/4D5E76D6-BFEB-41CE-BF3D-EBD2AA3820D7

Type series. Holotype: male, $\mathrm{CL}=37 \mathrm{~mm}$, ephemeral pan $200 \mathrm{~m}$ away from the western fence of False Bay Park (FB3), iSimangaliso Wetland Park $\left(27^{\circ} 57^{\prime} 31.33^{\prime \prime}\right.$, $32^{\circ} 21^{\prime} 42.15$ "E; elevation 62 m), 2 February 2015, R. Perissinotto, R.H. Taylor, D. Bilton, M.S. Bird, S.J. du Plooy and L. Clennell legit (ISAM A78908).

Allotype: female, $\mathrm{CL}=27 \mathrm{~mm}$, ephemeral pan, next to road leading from $\mathrm{Du}$ kandlovu campsite to False Bay Park entrance gate (FB5), 5 km south of Lister's Point, iSimangaliso Wetland Park (28 $0^{\circ} 51.70^{\prime \prime S}, 32^{\circ} 21^{\prime} 55.36 " E$; elevation $\left.10 \mathrm{~m}\right), 1$ February 2015, R. Perissinotto, R.H. Taylor, D. Bilton, M.S. Bird, S.J. du Plooy and L. Clennell legit (ISAM A78909).

Paratypes: one male, one female, collection data same as per holotype (NMMU); one male, ephemeral pan along the main road of False Bay Park (FB1), iSimangaliso Wetland Park (27 $58^{\prime} 32.02 " S, 32^{\circ} 21^{\prime} 51.62 " E$; elevation $\left.42 \mathrm{~m}\right), 1$ February 2015, R. Perissinotto, R.H. Taylor, D. Bilton, M.S. Bird, S.J. du Plooy, and L. Clennell 

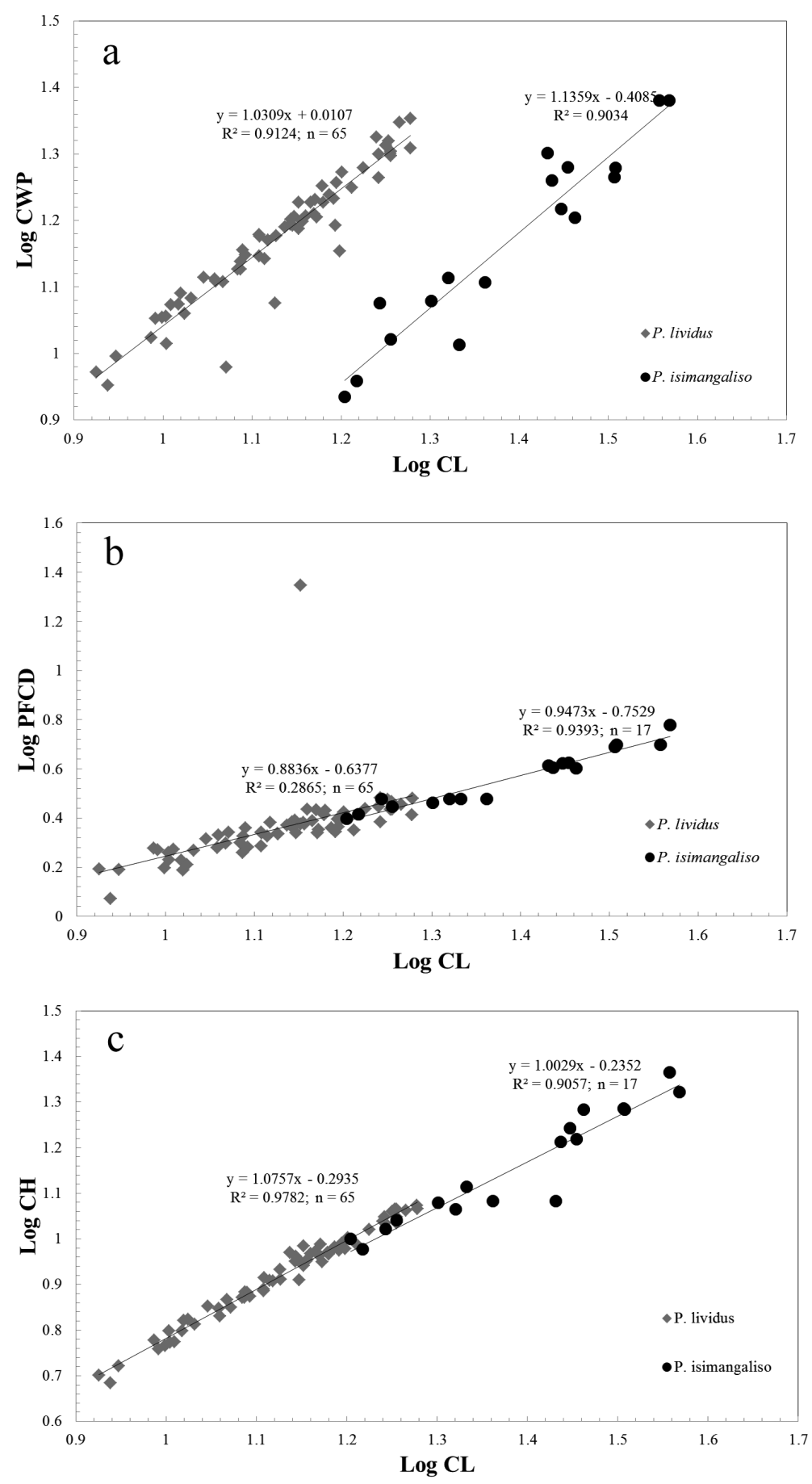

Figure 3. Regressions of a LogCWP over LogCL b LogPFCD over LogCL and c LogCH over LogCL between the two species $P$. isimangaliso and $P$. lividus. All differences between regressions were statistically significant $(\mathrm{p}<0.001)$. 
Table I. Morphometric variables $(\mathrm{mm})$ of Potamonautes isimangaliso sp. $\mathrm{n}$. holotype and paratype specimens.

\begin{tabular}{c|c|c|c}
\hline Variable & Holotype & Males $\mathbf{( n = 8 )}$ & Females $(\mathbf{n}=7)$ \\
\hline CL & 37 & $13.2-36.1$ & $18-27$ \\
\hline CWW & 55.1 & $18-53$ & $26-40.1$ \\
\hline CPW & 24 & $9-24$ & $10.5-20$ \\
\hline PFCD & 6 & $2-5$ & $2.8-4.1$ \\
\hline ED & 15.6 & $5-16$ & $8.5-12.8$ \\
\hline CWA & 34 & $14.1-40.5$ & $21.5-32$ \\
\hline CH & 21 & $7-23.2$ & $11-12.1$ \\
\hline AW6 & 12 & $3.1-11$ & $7-23.4$ \\
\hline MCPL & 49.3 & $11.5-44.5$ & $17.2-29.2$ \\
\hline MCPH & 21.9 & $4.1-20.1$ & $7-13.7$ \\
\hline P2ML & 21.3 & $6.5-18.9$ & $8.9-13.8$ \\
\hline P2MH & 6.5 & $2-6.1$ & $3-5$ \\
\hline
\end{tabular}

legit (ISAM A78910); one male, ephemeral pan, collection data same as per allotype (ISAM A78911); two males, two females, ephemeral pan along the main road of False Bay Park (FB1), iSimangaliso Wetland Park (2758'32.02"S, 32²1'51.62"E; elevation $42 \mathrm{~m}$ ), 31 January 2015, R. Perissinotto, R.H. Taylor, D. Bilton, M.S. Bird, S.J. du Plooy, and L. Clennell legit (ISAM A78912); two females, collection data same as per holotype, 26 November 2013, R. Perissinotto, R.H. Taylor, N. Peer, N.A.F. Miranda, M.S. Bird, J.L. Raw and L. Clennell legit (NMMU); one male, one female, ephemeral pan near Sandy Point in False Bay Park (FB 6), iSimangaliso Wetland Park

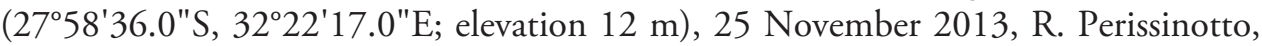
R.H. Taylor, N. Peer, N.A.F. Miranda, M.S. Bird, J.L. Raw and L. Clennell legit (ISAM A78913); two males, ephemeral pan, collection data same as per allotype, 5 December 2012, R. Perissinotto, N.A.F. Miranda, N. Peer, J.L. Raw legit (ISAM A78914).

Diagnosis. Main distinguishing features of P. isimangaliso from P. lividus Gouws, Stewart \& Reavell, 2001 as follows: slightly granulated, horizontal anterolateral margin more rounded than in P. lividus; downward projection of postfrontal crest at exorbital edges; uniform colouration of dark purplish brown with lighter or orange coloured joints, cheliped tips and pereopods tips. Potamonautes isimangaliso is larger than $P$. lividus, with a maximum size of $37 \mathrm{~mm}$ CL recorded in males.

Description. Carapace (Fig. 4a, c). Cephalothorax somewhat vaulted (CH/CL $=0.57)$, wide $(\mathrm{CWW} / \mathrm{CL}=1.49)$ and ovoid in general. Branchial region extremely rounded, forming a quarter of a circle with anterolateral margin. Anterior margin straight, lying on same horizontal plane as anterolateral margin; anterolateral margin slightly granulated. Urogastric grooves well-defined; cardiac and cervical grooves welldefined where attached to the urogastric groove, but then becoming poorly defined and shallow towards edge of carapace. Epigastric lobes well-defined above postfrontal crest by two indentations forked from midpoint of postfrontal crest. Postfrontal crest slightly granulated, curving forward medially. Postfrontal crest indistinct medi- 


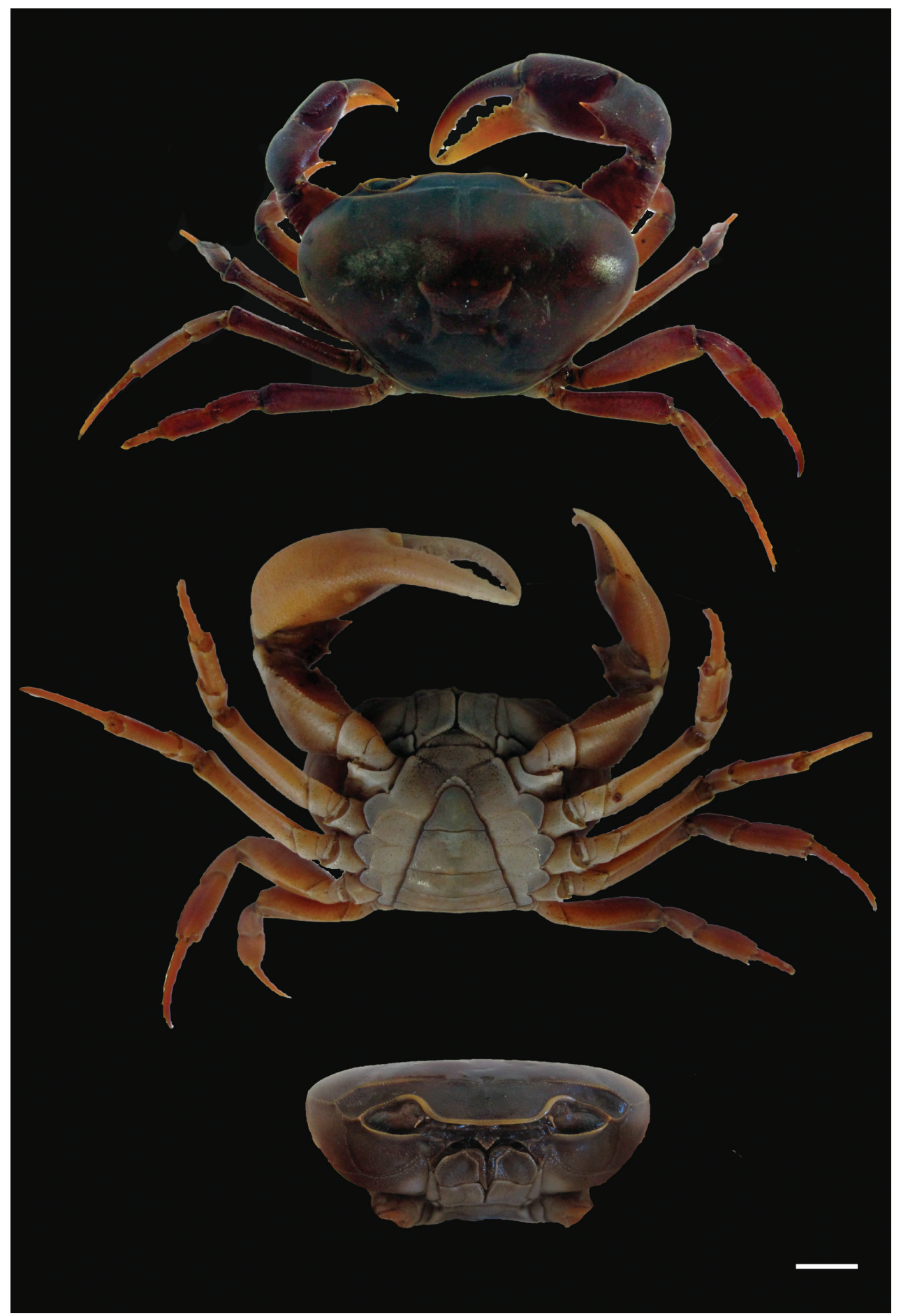

Figure 4. Potamonautes isimangaliso sp. $\mathrm{n}$. male holotype CWW $55.1 \mathrm{~mm}$ (ISAM A78908). a dorsal view $\mathbf{b}$ ventral view and $\mathbf{c}$ cephalothorax, frontal aspect. Scale bar: $10 \mathrm{~mm}$. Photos: Nasreen Peer. 


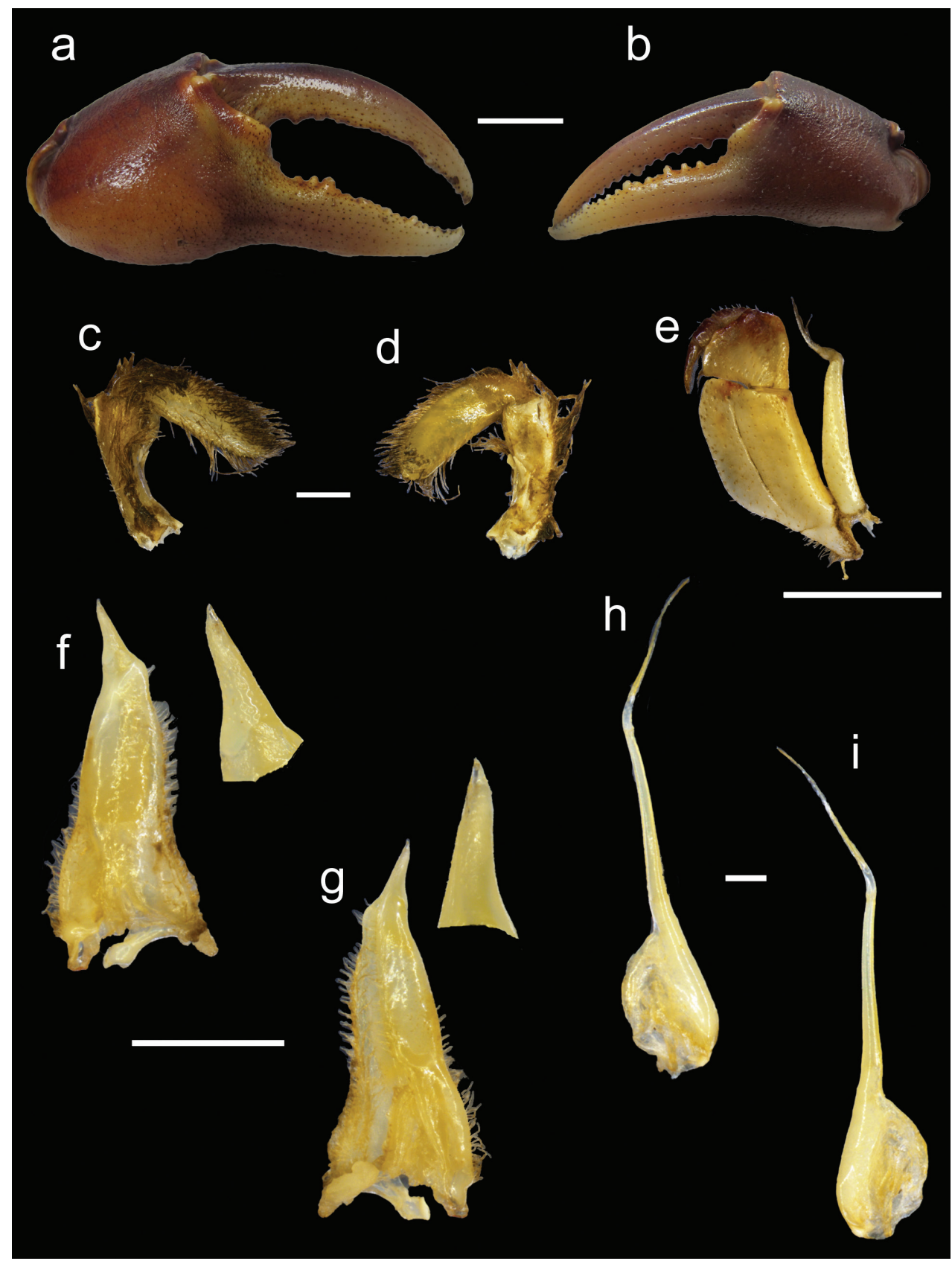

Figure 5. Potamonautes isimangaliso sp. $\mathrm{n}$. male holotype CWW $55.1 \mathrm{~mm}$ (ISAM A78908). a major cheliped $\mathbf{b}$ minor cheliped $\mathbf{c}$ right mandibular palp posterior view $\mathbf{d}$ right mandibular palp anterior view e $3^{\text {rd }}$ maxilliped $\mathbf{f}$ left gonopod 1 anterior view with enlarged terminal segment $\mathbf{g}$ left gonopod 1 posterior view with enlarged terminal segment $\mathbf{h}$ left gonopod 2 anterior view and $\mathbf{i}$ left gonopod 2 posterior view. Scale bars: $10 \mathrm{~mm}(\mathbf{a}, \mathbf{b}), 1 \mathrm{~mm}(\mathbf{c}, \mathbf{d}), 10 \mathrm{~mm}(\mathbf{e}), 5 \mathrm{~mm}(\mathbf{f}, \mathbf{g}), 1 \mathrm{~mm}(\mathbf{h}, \mathbf{i})$. Photos: Nasreen Peer. 
ally but pronounced posterior to orbital margins, curving prominently downwards at epibranchial region. Moderate presence of small exorbital teeth, but complete absence of epibranchial teeth. Flank of carapace smooth, with clear horizontal (epimeral) suture separating pterygostomial region from subhepatic and suborbital regions; vertical (pleural) groove dividing subhepatic region from suborbital region.

Sternites (Fig. 4b). Sternites 1 and 2 fused; first sulcus absent as a result; second sulcus s $2 / s 3$ prominent, running completely across sternum; third sulcus s $3 / s 4$ projecting downwards medially towards abdominopelvic region. Sulci and episternal sulci thereafter well-defined but shallow.

Third maxillipeds (Figs 4c, 5e). Filling entire buccal frame except transversely oval respiratory openings at top lateral corners. Ischium slightly scabrous, with pronounced groove running vertically. Flagellum on exopod of third maxilliped fairly long, curving upward at distal ends.

Mandibular palp (Fig. 5c, d). Consisting of two segments; terminal segment undivided and smooth, with dense tuft of setae protruding from base; hirsute margins; light covering of setae on posterior surface; subterminal segment enlarged distally where it joins with terminal segment.

Pereopods (Figs 4a, b, 5a, b). General right-handedness and prominent inequality of chelae where CRDL/CLDL $=1.32$. Dactyl of major chela moderately arched; large interspace formed in major cheliped when fingers are closed, long slim interspace formed by closing of fingers in minor cheliped. Twenty four cutting teeth present on the dactyl of major cheliped and 29 on dactyl of minor cheliped; 3 larger and more prominent than the rest. Propodus fairly inflated; right propodus larger (CRPL/ CLPL $=1.41)$ and wider $(C R P W / C L P W=1.75)$ than left. Left pollex with 25 cutting teeth and right propodus with 18. Carpus on either side containing one prominent tooth followed by one smaller tooth. Meri strongly granulated around margins; slender pereopods (pereopod 2: ML/MW = 3.28; pereopods 5: ML/MW = 2.17), pereopod 3 is longest and pereopod 5 shortest; ventral margins of meri smooth; ventral margins of propodi slightly serrated; dorsal margins of meri and propodi bearing fine sharp bristles; dactyli serrated and ending in sharp points.

Pleon (Fig. 4b). First five segments broad and short, with segments 6 and 7 longer; segments 1-6 four sided, with triangular distally-rounded terminal segment (telson).

Pleopods (Fig. 5f, g, h, i). Gonopod 1 bearing short terminal segment only 0.23 times the length of the subterminal segment. Terminal segment curving slightly away from midline when viewed posteriorly. Gonopod widest at base, with both subterminal and terminal segments tapering and ending in sharp point. Inner lateral margin of subterminal segment irregular; outer lateral margin curving in a concave manner towards middle of gonopod; both margins hirsute. Groove extending almost through entire length of gonopod, visible on posterior surface, lined with setae. Distal margin of subterminal segment irregularly curved. Gonopod 2 consisting of two segments; terminal segment relatively long ( 0.47 times length of subterminal segment), very slim; subterminal segment wide at base, sharply becoming very narrow around 0.4 of length at which point narrow process forms, leading up to terminal segment. Small tuft of 
setae present on outer margin of base of subterminal segment. Gonopod 2 curved, moving outwards away from medial line of gonopod proximally, curving back towards medial line distally.

Variation. The major cheliped does not always display a pronounced interspace when fingers are closed. In juveniles and in the female allotype this was less prominent. The arching of chelipeds varies too, with some (particularly the minor chelipeds) bearing straight dactyli while others are fairly rounded. All collected specimens display a pronounced heterochely and all appear to be right-handed.

Live colouration. Colouration of carapace may vary between light brown, maroon, purplish-brown and almost black. Similarly, tips of dactyli may be either orange, bright yellow or a dull yellow.

Distribution. Currently only known from the False Bay region of the iSimangaliso Wetland Park on the north-east coast of South Africa.

Type locality. South Africa, KwaZulu-Natal, iSimangaliso Wetland Park, False Bay - Western Shores: Mpophomeni Pan (2757'31.33"S, 32²1'42.15"E); Du-

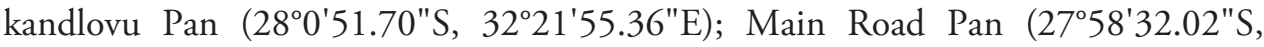
$\left.32^{\circ} 21^{\prime} 51.62^{\prime \prime E}\right)$; Sandy Point Pan (275' $\left.36.0^{\prime \prime S}, 32^{\circ} 22^{\prime} 17.0^{\prime \prime E}\right)$.

Etymology. The species is named after the iSimangaliso Wetland Park, located in northern KwaZulu-Natal, where it is currently thought to be micro-endemic. This is significant as the iSimangaliso Wetland Park falls within the Maputaland centre of endemism (Smith et al. 2008), highlighting the importance of this park as a global biodiversity hotspot. The Park is a UNESCO World Heritage Site and contains three Ramsar Wetlands of International Importance.

Remarks. Potamonautes isimangaliso sp. n. is easily distinguishable from most other Potamonautes spp. found in South Africa. Potamonautes dentatus Stewart, Coke \& Cook, 1995, P. parvispina Stewart, 1997, P. unispinus Stewart \& Cook, 1998, P. warreni Calman, 1918 and P. calcaratus (Gordon, 1929) all bear dentate anterolateral margins or epibranchial corners, while $P$. isimangaliso has a rounded epibranchial corner and mildly granular anterolateral margin.

Potamonautes perlatus (H. Milne Edwards, 1837), P. granularis Daniels, Stewart \& Gibbons, 1998, P. sidneyi Rathbun, 1904, P. barbarai Phiri \& Daniels, 2014 and P. barnardi Phiri \& Daniels, 2014 all have sharply-defined scabrous or granular epibranchial corners and prominent postfrontal crest, while $P$. isimangaliso has a heavily rounded smooth epibranchial corner and poorly-defined postfrontal crest. Potamonautes parvicorpus Daniels, Stewart \& Burmeister, 2001 also displays a finely granulated anterolateral margin and rounded epibranchial corners, but the resemblance to $P$. isimangaliso is superficial, as it differs in the indentation of its anterior margin where $P$. parvicorpus bears a slightly indented anterior margin while that of $P$. isimangaliso lies straight. Further differences are seen in locality as the habitat of $P$. parvicorpus is restricted to high mountain streams in the Western Cape (Daniels et al. 2001).

Potamonautes clarus Gouws, Stewart \& Coke, 2000, P. depressus (Krauss, 1843), P. brincki (Bott, 1960), P. flavusjo Daniels, Phiri \& Bayliss, 2014 and P. lividus Gouws, Stewart \& Reavell, 2001 all have smooth anterolateral margins and rounded smooth 
epibranchial corners but bear differences compared to $P$. isimangaliso. One of the diagnostic characters of $P$. depressus is the dorsally flattened carapace, where CL/CH = 2.3-2.6. Potamonautes isimangaliso has a more vaulted carapace with a CL/CH ratio of 1.6-1.8. Potamonautes brincki and P. clarus are smaller crabs ( $\max C L=27 \mathrm{~mm}$ in males for both species), preferring fast-flowing mountain stream habitats. Potamonautes flavusjo is ecologically distinct from $P$. isimangaliso and can be found in the Mpumalanga Highveld. In addition to this, the species is smaller and has flattened chelipeds, not adapted for burrowing (Daniels et al. 2014). Light yellow chelipeds and ventral surfaces of pereopods characterise P. flavusjo.

Potamonautes lividus shares a similar distribution, outward appearance and preference for air-breathing with $P$. isimangaliso. However various differences exist between the two species. The level and angle of anterolateral margin differ, where $P$. isimangaliso bears an anterolateral margin lying on the same horizontal plane as the anterior margin. Conversely, $P$. lividus has an anterolateral margin which angles downward to join the anterior margin and thus sits higher than the anterior margin. The downward angle of postfrontal crest at exorbital edges is seen in $P$. isimangaliso but not in $P$. lividus. Carapace flatness is indicated by the $\mathrm{CL} / \mathrm{CH}$ ratio which equates to 1.5 for $P$. lividus and 1.8 for $P$. isimangaliso holotypes. The maximum size $(37 \mathrm{~mm} \mathrm{CL}$ in $P$. isimangaliso and $25.5 \mathrm{~mm}$ CL in P. lividus), colouration (dark blue carapace with bright orange chelipeds in P. lividus and dark brown/purple carapace with brown or dull yellow cheliped in $P$. isimangaliso), inflation of chela with gap between propodus and dactyl (dactyl of $P$. lividus is more arched than that of $P$. isimangaliso) and the number of poorly-developed teeth on carpus ( $P$. lividus containing one prominent and three rudimentary teeth; $P$. isimangaliso containing one prominent and one rudimentary tooth) further distinguish the two species. Gonopods of both species are very similar with the only difference being the tuft of setae found at the base of pleopod 2 in P. isimangaliso. Specimens resembling P. lividus were found in the Dwesa Forest, Eastern Cape and appear to be genetically nearly identical to $P$. lividus (Daniels et al. 2014). This further substantiates the genetic distinctiveness of $P$. isimangaliso. The smallest mature male of $P$. isimangaliso recorded had a CL of $13.2 \mathrm{~mm}$ whilst all females recorded were mature $(\mathrm{min} \mathrm{CL}=18 \mathrm{~mm})$.

Preliminary sequence data for two mitochondrial gene regions (16S: GenBank accession number KR137640; COI: KR137642) generated from a representative of the new species, using approaches described elsewhere (Daniels et al. 2002; Phiri and Daniels 2014; G. Gouws unpubl.), were notably divergent (7.3\% and 7.9\%, respectively) from published 16S (AY042248; Daniels et al. 2002) and COI (AF510879; Daniels et al. 2002) sequences of Potamonautes lividus from KwaZulu-Natal.

Habitat and ecology. Potamonautes isimangaliso sp. n. inhabits freshwater ephemeral pans (maximum salinity recorded: 0.75 ) which fill up with fresh, oxygen-deprived water after rainfall events, mainly during the summer wet season. These pans are located along the western shores of False Bay, Lake St Lucia (Fig. 6a-d) in clearings of the sand forest biome of False Bay and are generally partially shaded. Potamonautes isimangaliso and $P$. lividus are found in close proximity although $P$. lividus has not 


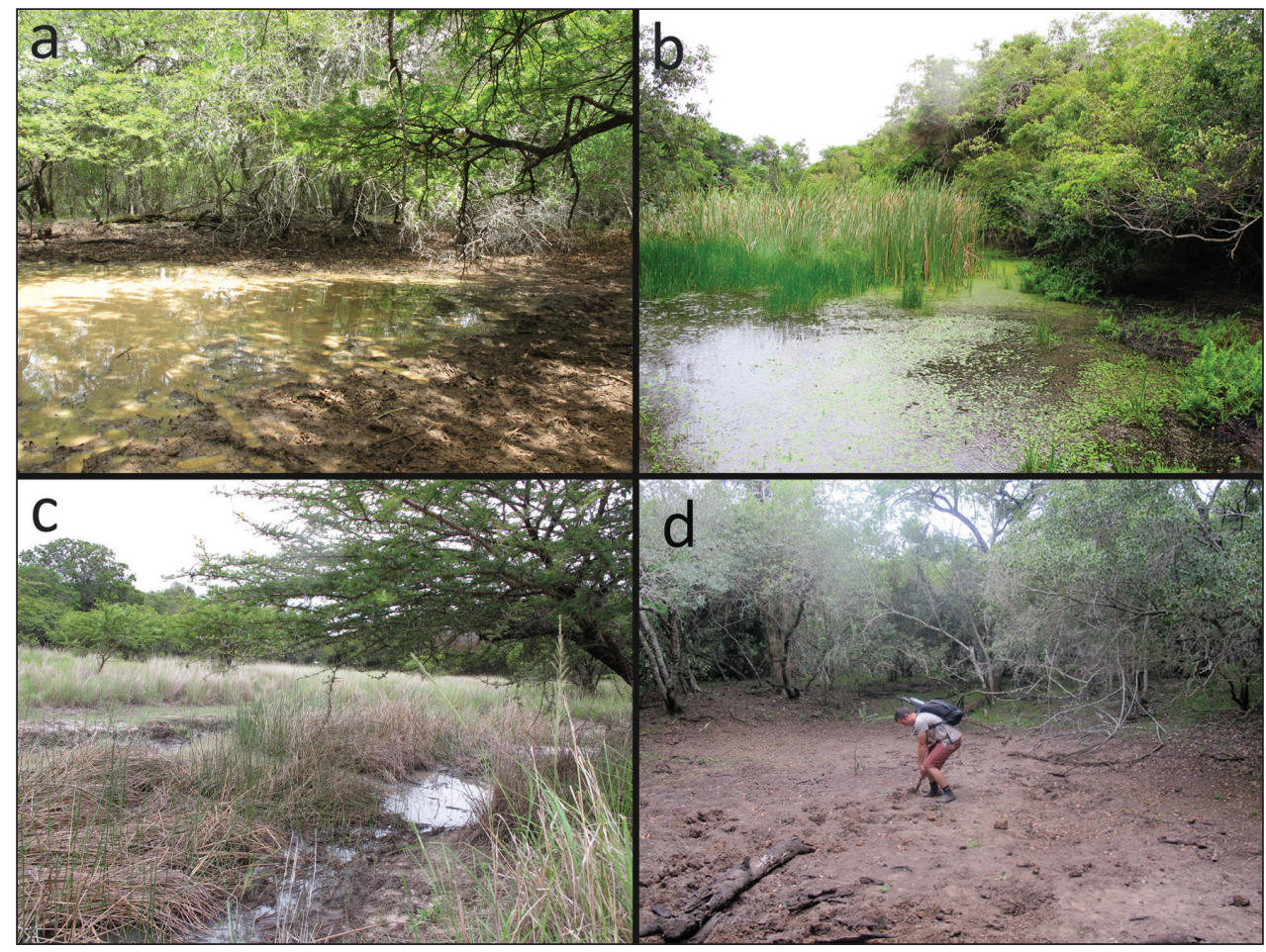

Figure 6. Sampling localities of Potamonautes isimangaliso sp. n.: a Main Road Pan (FB1) b Mpophomeni Pan (FB3) c Dukandlovu Pan (FB5) and d Sandy Point Pan (FB6), completely dry during Feb 2015. Photos: a-c Lynette Clennell; d Nasreen Peer.

been found in False Bay Park and P. isimangaliso has not been found outside of the park. Furthermore, a difference in habitat type between $P$. isimangaliso and P. lividus Gouws, Stewart \& Reavell, 2001 is seen, where the latter is known to inhabit burrows well above the surface water line in Ficus and Barringtonia swamps (Gouws et al. 2001), while the new species was found in close association with ephemeral pans in sand forest habitat with burrows extending below the surface waterline. Vegetation types include the dominant canopy species Cleisthantus schlechteri, Hymenocardia ulmoides, Psydrax fragrantissima, Croton pseudopulchellus and Drypetes arguta (Kirkwood \& Midgley, 1999), as well as various Acacia spp. (Moll 1980). Grass species such as Paspalum vaginatum and Eleochoris sp. are also closely associated with this environment (Moll 1980). Aquatic plants associated with the ephemeral pans include the reed Typha capensis, the sedge Juncus kraussii, the mangrove fern Acrostichum aureum and the duckweed Lemna sp. (Howard-Williams 1980).

Potamonautes isimangaliso adults form burrows on the banks of these pans (Fig. 7a), while juveniles are found either in burrows or free-crawling in shallow water $(2-50 \mathrm{~cm})$. The species lives sympatrically with $P$. sidneyi but is separated by habitat 
Table 2. Physico-chemical parameters of sampling localities $\dagger$.

\begin{tabular}{c|c|c|c|c}
\hline & $\begin{array}{c}\text { Main Road Pan } \\
(\text { FB1) }\end{array}$ & $\begin{array}{c}\text { Mpophomeni } \\
\text { Stream (FB2) }\end{array}$ & $\begin{array}{c}\text { Mpophomeni } \\
\text { Pan (FB3) }\end{array}$ & $\begin{array}{c}\text { Dukandlovu Pan } \\
\text { (FB5) }\end{array}$ \\
\hline Temperature $\left({ }^{\circ} \mathrm{C}\right)$ & 26.1 & 20.4 & 22.03 & 26.73 \\
\hline Salinity & 0.15 & 8.36 & 0.29 & 0.75 \\
\hline Maximum depth (mm) & 80 & 500 & 700 & 250 \\
\hline $\mathrm{pH}$ & 7.2 & 7.03 & 7.42 & 6.9 \\
\hline Turbidity (NTU) & 1310.5 & 14 & 151 & 306.3 \\
\hline Dissolved oxygen (\% sat.) & 19.8 & 90.1 & 22.4 & 69.6 \\
\hline
\end{tabular}

$\dagger \quad$ No data is included for Sandy Point Pan (FB6) as the site was dry at the time of sampling.

type, with $P$. sidneyi inhabiting flowing streams and able to withstand higher salinities of up to 9 (18 May 2013, Mpophomeni Stream, 2757'7.17"S, 32²2'37.21"E). Oxygen levels in the pans inhabited by $P$. isimangaliso are quite low compared to flowing streams (Table 2).

Although the species appears to be more closely associated with water than its morphologically closest congener, P. lividus (Gouws et al. 2001), the low levels of oxygen characteristic of the pans along with the ephemeral nature of the waterbodies indicate a greater affinity for a terrestrial lifestyle, as it may be more effective to obtain oxygen through air-breathing. This has been recorded previously in various African freshwater brachyuran genera and a high-vaulted carapace may be indicative of this change, where periods of dryness favour the evolution of burrowing semi-terrestrial, air-breathing tendencies (Cumberlidge 1999; Cumberlidge 2009). Specimens of $P$. isimangaliso have been observed in deep burrows $(30-50 \mathrm{~cm})$ around desiccated pools. Because the rainy season in this area is generally restricted to the period November-April (late Austral spring to early Autumn), much of the population hibernates deep in the mud, where traces of moisture persist throughout the dry season. Crabs return to the surface only after major rainfall events have filled up the ephemeral pools. The summer of 2014-2015 had been particularly dry in the area, with substantial rain falling in the False Bay area starting only in the middle of January (69 mm during 15-17 Jan, $54 \mathrm{~mm}$ during 28-30 Jan 2015; False Bay Park Meteo Station). Numerous adult and sub-adult crabs were observed from 31 Jan to 3 Feb in the newly filled ephemeral pools but hardly any young juvenile, indicating that the previous drought conditions had not allowed spawning to happen yet.

The feeding ecology of the species is largely unknown, although Potamonautes crabs are generally thought to shift from a diet of aquatic invertebrates to a more herbivorous or opportunistic diet with age (Hill and O'Keeffe 1992). The chelar dentition is serrate and the larger crusher chela lacks rounded or molariform occlusive geometry in the proximal region, probably due to wearing down over time. The dentition of the chela is indicative of an opportunistic omnivorous diet (Yamada and Boulding 1998). 


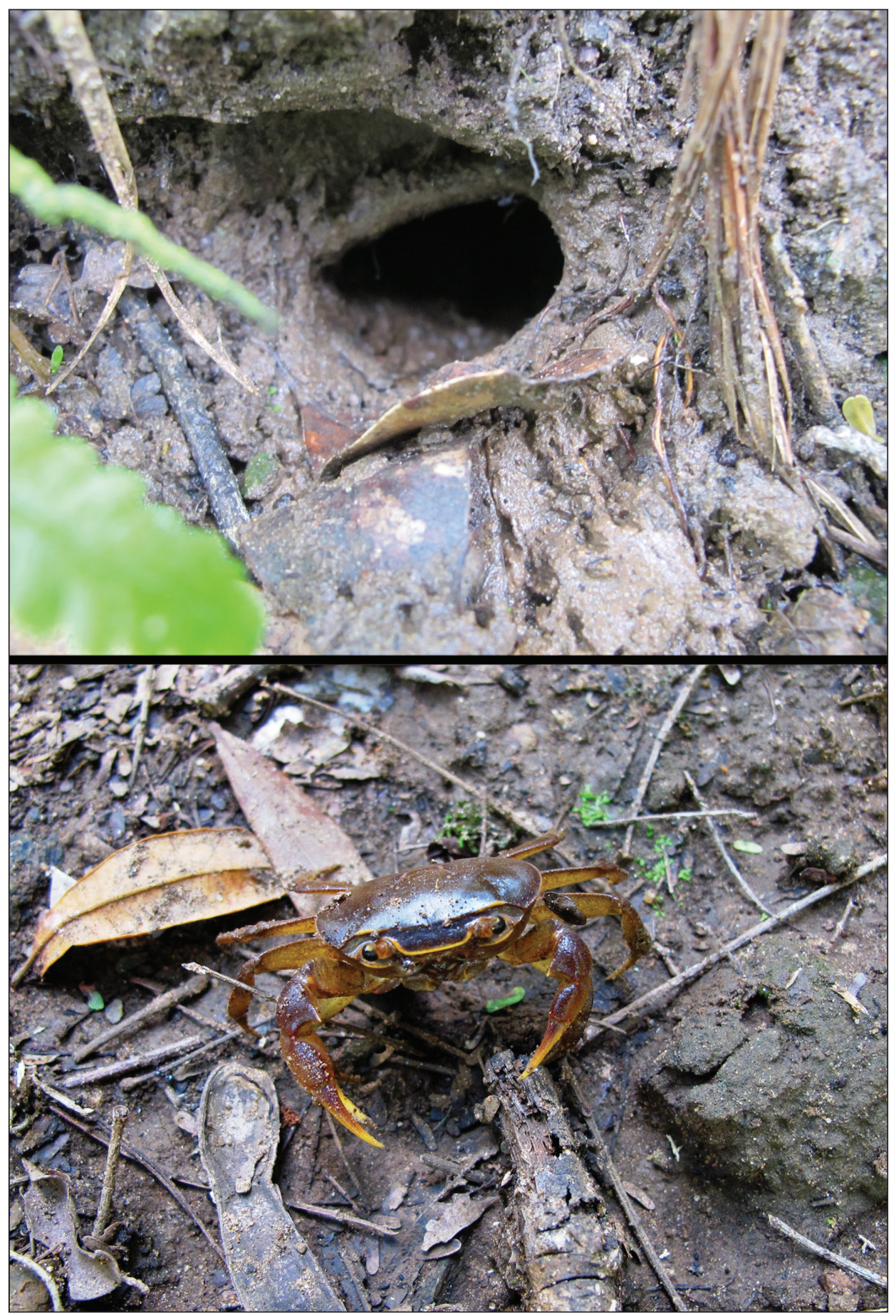

Figure 7. A Burrows of Potamonautes isimangaliso sp. n. are typically found on the banks of ephemeral pans and are even maintained when pans are completely dry B Potamonautes isimangaliso sp. $\mathrm{n}$. in its natural habitat. Photos: Lynette Clennell. 


\section{Updated key for the identification of the Potamonautes species of South Africa}

Based on Day et al. (2001)

1 Anterolateral margin bearing one tooth or many distinct teeth ...................2

- $\quad$ Anterolateral margin smooth tooth, sometimes serrated or granulated ........6

2 Anterolateral margin bearing two or more distinct teeth ..............................3

- $\quad$ Anterolateral margin bearing one distinct tooth at epibranchial corner .......4 4

3 Postfrontal crest complete to anterolateral margin; epibranchial sinus absent..

Potamonautes warreni Calman, 1918

- $\quad$ Postfrontal crest interrupted at exorbital teeth; epibranchial sinus present ....

4 Postfrontal crest not continuous posterior to exorbital teeth; merus of chelipeds bearing a spine on both antero- and posterior-inferior granulate margins.......................................................... P. calcaratus (Gordon, 1992) Postfrontal crest complete; no spine on merus of cheliped ........................... 5

5 Postfrontal crest not sloping backwards towards anterolateral margin; epibranchial sinus absent .........................P. unispinus Stewart \& Cook, 1998

- $\quad$ Postfrontal crest sloping backwards to meet anterolateral margin; epibranchial sinus present............................................... P. parvispina Stewart, 1997

6 Anterolateral margin granulated, forming distinct angle with postfrontal crest at epibranchial corner; epibranchial region usually scabrous or granulated....7

- Anterolateral margin rounded and smooth, meeting postfrontal crest at rounded epibranchial corner; epibranchial region usually without scabrosity or granulation

Carapace and postfrontal crest strongly granulated, with pronounced scabrosity in epibranchial region

Carapace and postfrontal crest moderately granulated, with relatively smooth epibranchial region

Carapace anterior relatively narrow and curved moderately over the branchial region; inward-extending lobe absent from short terminal segment of gonopod 2; confined to the Olifants River system in the Cape Fold Mountains below the Bulshoek dam wall (WC)

P. granularis Daniels, Stewart \& Gibbons, 1998

Carapace anterior relatively wide and curved slightly over the branchial region; long slender S-shaped terminal segment of gonopod 2 is formed by inward extending lobe; not occurring in the Western Cape...... P. sidneyi Rathbun, 1904 Occurring largely in the Western Cape, also extending further north and east; found in western flowing drainage systems including the Olifants River, where it occurs above the Bulshoek dam wall.

- $\quad$ Restricted to southern flowing drainages in the Western Cape (Gamtoos River and Gourits River) .P. barbarai Phiri \& Daniels, 2014 
- $\quad$ Restricted to the Berg River and tributaries of the Breede River (WC)

P. barnardi Phiri \& Daniels, 2014

10 Carapace depressed and dorso-ventrally flattened; ratio of carapace length to height between 2.1 and 2.6.....

- $\quad$ Carapace vaulted and arched; ratio of carapace length to height between 1.5 and 2.2

11 Carapace flatter, with a ratio of carapace length to carapace height between 2.3 and 2.6; postfrontal crest often directed forward near anterolateral margin; dark yellow-brown or green-brown in colour P. depressus (Krauss, 1843)

- $\quad$ Carapace more vaulted, with ratio of carapace length to carapace height between 2.1 and 2.3; postfrontal crest straight near the anterolateral margin; orange in colour. P. clarus Gouws, Stewart \& Coke, 1995

12 Dactyli of chelipeds flattened; postfrontal crest, pereopods and chelipeds bright yellow; occurring in the Mpumalanga Highveld.

P. flavusjo Daniels, Phiri \& Bayliss, 2014

- Dactyl of chelipeds moderately or highly arched ..................................13

13 Anterolateral margin curving inward over carapace surface in the branchial region; occurring in $\mathrm{KZN}$............................................................... 14

- $\quad$ Anterolateral margin not curving inward over carapace surface in the branchial region; occurring in the WC ............................................................. 15

14 Bearing one prominent tooth and three rudimentary teeth on carpus of cheliped; tuft of setae absent from base of pleopod 2; carapace dark with distinctive blue sheen; chelipeds and pereopods bright orange

P. lividus Gouws, Stewart \& Reavell, 2001

- $\quad$ Bearing one prominent tooth and one rudimentary tooth on carpus of cheliped; tuft of setae present at base of pleopod 2; carapace uniformly purplish brown with similar coloured or slightly brighter chelipeds and pereopods.

P. isimangaliso sp. $\mathrm{n}$.

Flange present on terminal segment of mandibular palp...P. brincki (Bott, 1960) Flange absent from terminal segment of mandibular palp.

P. parvicorpus Daniels, Stewart \& Burmeister, 2001

\section{Acknowledgements}

The authors are grateful to R.H. Taylor, L. Clennell, D. Bilton, M.S. Bird, S.J. du Plooy and J.L. Raw for assistance with collections. L. Clennell is acknowledged for photography. P-P. Steyn and J.B Adams are thanked for their help with plant identification. The iSimangaliso Wetland Park Authority and Ezemvelo KZN Wildlife are also gratefully acknowledged for providing logistical assistance and permits for this project. We are grateful to Thobile Ndlovu for providing rainfall data for the area. This work is based on the research supported by the South African Research 
Chairs Initiative of the Department of Science and Technology (DST) and National Research Foundation (NRF) of South Africa. Any opinion, finding and conclusion or recommendation expressed in this material is that of the author(s) and the NRF does not accept any liability in this regard.

\section{References}

Bott R (1960) Crustacea (Decapoda): Potamonidae. In: Hanström B, Brinck P, Rudebeck G (Eds) South African animal life: results of the Lund University expedition in 1950-1951, vol. 7. Almqvist \& Wiksells, Uppsala, 13-18.

Calman WT (1918) A new river crab from the Transvaal. Annals and Magazine of Natural History 9: 234-236. doi: 10.1080/00222931808562306

Cumberlidge N (1999) The Freshwater Crabs of West Africa: Family Potamonautidae. IRD Editions, Paris, France, 385 pp.

Cumberlidge N (2009) The status and distribution of freshwater crabs. In: Smith KG, Diop MD, Niane M, Darwall WRT (Eds) The Status and Distribution of Freshwater Biodiversity in Western Africa. IUCN \& Wetlands International report, Gland, Switzerland and Cambridge, UK, 56-72.

Daniels SR, Bayliss J (2012) Neglected refugia of biodiversity: mountainous regions in Mozambique and Malawi yield two novel freshwater crab species (Potamonautidae: Potamonautes). Zoological Journal of the Linnaean Society 164: 498-509. doi: 10.1111/j.10963642.2011.00773.x

Daniels SR, Phiri EE, Bayliss J (2014) Renewed sampling of inland aquatic habitats in southern Africa yields two novel freshwater crab species (Decapoda: Potamonautidae: Potamonautes). Zoological Journal of the Linnaean Society 171: 356-369. doi: 10.1111/zoj.12139

Daniels SR, Stewart BA, Gouws G, Cunningham M, Matthee CA (2002) Phylogenetic relationships of the southern African freshwater crab fauna (Decapoda: Potamonautidae: Potamonautes) derived from multiple data sets reveal biogeographic patterning. Molecular Phylogenetics and Evolution 25: 511-523. doi: 10.1016/S1055-7903(02)00281-6

Daniels SR, Stewart BA, Burmeister L (2001) Geographic patterns of genetic and morphological divergence amongst populations of a river crab (Decapoda, Potamonautidae) with the description of a new species from mountain streams in the Western Cape, South Africa. Zoologica Scripta 30: 181-197. doi: 10.1046/j.1463-6409.2001.00061.x

Daniels SR, Stewart BA, Gibbons MJ (1998) Potamonautes granularis sp. nov. (Brachyura, Potamonautidae), a new cryptic species of river crab from the Olifants River System, South Africa. Crustaceana 71: 885-903. doi: 10.1163/156854098X00905

Day JA, Stewart BA, de Moor IJ, Louw AE (2001) Guides to the Freshwater Invertebrates of Southern Africa Volume 4: Crustacea III. WRC Report No. TT 141/01, South Africa.

Dobson M (2004) Freshwater crabs in Africa. Freshwater Forum 21: 3-26.

Gordon I (1929) A new river-crab of the subgenus Potamonautes from Portuguese East Africa. Annals and Magazine of Natural History 3: 405-411. doi: 10.1080/00222932908672988 
Gouws G, Stewart BA, Reavell PE (2001) A new species of freshwater crab (Decapoda, Potamonautidae) from the swamp forests of KwaZulu-Natal, South Africa: biochemical and morphological evidence. Crustaceana 74: 137-160. doi: 10.1163/156854001750096256

Gouws G, Stewart BA, Coke M (2000) Evidence for a new species of river crab (Decapoda, Brachyura, Potamonautidae) from the Drakensberg, South Africa. Journal of Crustacean Biology 20: 743-758. doi: 10.1163/20021975-99990096

Hill MP, O'Keeffe JH (1992) Some aspects of the ecology of the freshwater crab (Potamonautes perlatus Milne Edwards) in the upper reaches of the Buffalo River, Eastern Cape Province, South Africa. South African Journal of Aquatic Science 18: 42-50. doi: 10.1080/10183469.1992.9631323

Howard-Williams C (1980) Aquatic macrophytes of the coastal wetlands of Maputaland. In: Kirkwood D, Midgley JJ (1999) The floristics of Sand Forest in northern KwaZulu-Natal, South Africa. Bothalia 29: 293-304.

Krauss F (1843) Südafrikanischen Crustaceen. Eine Zusammenstellung aller bekannten Malacostraca, Bemerkungen über deren Liebenswiese und geographische Verbreitung, nebst beschreibung und Abbildung mehrer neuen arten. E. Schweizerbart'sche Verlagsbuchhandlung, Stuttgart.

Milne Edwards H (1834-1840) Histoire naturelle des Crustaces, comprenant I'anatomie, la physiologie et la classification des ces animaux. Second edition. Librairie encyclopédique de Roret, Paris.

Moll EJ (1980) Terrestrial plant ecology. In: Bruton MN, Cooper KH (Eds) Studies on the Ecology of Maputaland. Rhodes University, Grahamstown and Wildlife Society of Southern Africa, Durban, 52-68.

Nel HA, Perissinotto R, Taylor RH (2012) Diversity of bivalve molluscs in the St Lucia Estuary, with an annotated and illustrated checklist. African Invertebrates 53: 503-525. doi: 10.5733/afin.053.0210

Peer N, Perissinotto R, Taylor RH, Miranda NAF (2014) Temporal variations in the diversity of true crabs (Crustacea: Brachyura) in the St Lucia Estuary, South Africa. African Invertebrates 55: 39-65. doi: 10.5733/afin.055.0103

Perissinotto R, Miranda NAF, Raw JL, Peer N (2014) Biodiversity census of Lake St Lucia, iSimangaliso Wetland Park (South Africa): Gastropod molluscs. Zookeys 440: 1-43. doi: 10.3897/zookeys.440.7803

Phiri EE, Daniels SR (2014) Disentangling the divergence and cladogenesis in the freshwater crab species (Potamonautidae: Potamonautes perlatus sensu lato) in the Cape Fold Mountains, South Africa, with the description of two novel cryptic lineages. Zoological Journal of the Linnaean Society 170: 310-332. doi: 10.1111/zoj.12103

Rathbun MJ (1904) Les Crabes d'Eau Douce (Potamonidae) 2. Nouvelles Archives du Muséum d'Histoire Naturelle (Paris) 7: 159-322.

Schuwerack PMM, Lewis JW, Jones P (2001) The potential use of the South African river crab, Potamonautes warreni, as a bioindicator species for heavy metal contamination. Ecotoxicology 10: 159-166. doi: 10.1023/A:1016689810391

Smith RJ, Easton J, Nhancale BA, Armstrong AJ, Culverwell J, Dlamini SD, Goodman PS, Loffler L, Matthews WS, Monadjem A, Mulqueeny CM, Ngwenya P, Ntumi CP, Soto 
B, Leader-Williams N (2008) Designing a transfrontier conservation landscape for the Maputaland centre of endemism using biodiversity, economic and threat data. Biological Conservations 141: 2127-2138. doi: 10.1016/j.biocon.2008.06.010

Stewart BA (1997) Biochemical and morphological evidence for a new species of river crab Potamonautes parvispina sp. nov. (Brachyura, Potamonautidae). Crustaceana 70: 737-753. doi: 10.1163/156854097X00168

Stewart BA, Cook PA (1998) Identification of a new species of river crab (Decapoda: Brachyura: Potamonautidae) from South Africa using morphological and genetic data. Journal of Crustacean Biology 18: 556-571. doi: 10.2307/1549420

Stewart BA, Coke M, Cook PA (1995) Potamonautes dentatus, new species, a fresh-water crab (Brachyura: Potamoidea: Potamonautidae) from KwaZulu-Natal, South Africa. Journal of Crustacean Biology 15: 558-568. doi: 10.2307/1548776

Yamada SB, Boulding EG (1998) Claw morphology, prey size selection and foraging efficiency in generalist and specialist shell-breaking crabs. Journal of Experimental Marine Biology and Ecology 220: 191-211. doi: 10.1016/S0022-0981(97)00122-6

Yeo DCJ, Cumberlidge N, Klaus S (2014) Preface-freshwater decapod biology in the $21^{\text {st }}$ Century. In: Yeo DCJ, Cumberlidge N, Klaus S (Eds) Advances in freshwater decapod systematics and biology, 1-6. 